\title{
Effect of lemongrass and mint essential oils combined with food additives soaking solution on the quality of Pangasius fillets during cold storage
}

\author{
Sarnes, R., ${ }^{*}$ Ngoc, T.T.A. and Binh, L.N. \\ Food Technology Department, College of Agriculture, Can Tho University, Can Tho, Vietnam
}

\author{
Article history: \\ Received: 8 April 2020 \\ Received in revised form: 17 \\ August 2020 \\ Accepted: 13 December 2020 \\ Available Online: 27 \\ December 2020
}

\section{Keywords:}

Lemongrass essential oil,

Mint essential oil,

Pangasius fillets,

Shelf life

\section{DOI:}

https://doi.org/10.26656/fr.2017.4(S6).001

\begin{abstract}
Pangasius fillet has high demand in the international market due to its tender flesh, delicate taste and as an affordable substitute for cod and other more expensive white fishes. The preliminary study, it was found that the optimized condition for soaking was $\mathrm{NaCl} 1.32 \%$, STPP $1.88 \%$, and sorbitol $4.68 \%$ for 30 mins which give a significant effect $(p<0.05)$ to the yield, water activity, $\mathrm{pH}$, and improvement in the sensory of the treated fillet. However, the soaking itself was not contributed to the extension of shelf life. This study aimed to examine the effects of Pangasius fillet soaked in essential oil on the quality and shelf life with simulated storage similar to retail conditions. Lemongrass essential oil was showing the best result in improving the quality and shelf life of Pangasius fillet stored in refrigerated storage $\left(0-4^{\circ} \mathrm{C}\right)$. The addition of $0.2 \%$ lemongrass showed 7 days extension of shelf-life or longer compared to fillet without soaking and fillet soaking without essential oil. In addition, it also reduces the Total Volatile BasedNitrogen (TVB-N) content, improves the sensory quality (raw and cooked) of Pangasius fillet. Mint essential oil was showing the shelf-life extension (7 days longer) and sensory improvement at $0.3 \%$ concentration. However, the mint essential oil was not showing better TVB-N reduction in treated fillet compared to fillet soaking without essential oil. Therefore, it is recommended to incorporate $0.2 \%$ lemongrass essential oil for the Pangasius industry to extend the shelf life of Pangasius fillet followed with quality improvement.
\end{abstract}

\section{Introduction}

Pangasius hypophthalmus or also known as sutchi catfish, striped catfish, or tra fish is mainly produced in Vietnam (Phan et al., 2009). Frozen fillets and thawed fillets are the most popular Pangasius product sold in supermarkets and fresh markets in Western countries (Orban et al., 2008). Pangasius fillet has tender flesh, sweet taste, absence of fishy odour and spines, delicate flavour and firm texture when cooked. Therefore, Pangasius is now largely accepted as an affordable substitute for cod and other more expensive white fishes and also due to their good nutritional quality (Phan et al., 2009; Karl et al., 2010).

As a highly perishable food (Orban et al., 2008), extra attention should be given to prolong the shelf life of Pangasius fillet. Food antimicrobial agent is one of the chemicals added to prolong shelf life. However, several questions about the safety of chemicals used for food preservation were raised due to the suspected negative effects on consumer's health (Cassens, 1997).
The ability of plant essential oils to protect foods against pathogenic and spoilage microorganisms has been reported by Burt (2004) and Ahmad et al. (2012) The essential oils (EOs) contain phenolic compounds such as thymol, carvacrol, p-cymene, and $\gamma$-terpinene and have been known to inhibit both gram-negative and grampositive microorganisms (Burt, 2004). Therefore, the usage of essential oils as natural food additives became common, since they possess antibacterial, antiviral, and antimycotic properties (Ahmad et al., 2012).

In industry, soaking fillet with food additives such as sorbitol, sodium tripolyphosphate (STPP) and sodium chloride $(\mathrm{NaCl})$ is the common practices to increase the yield, maintain the texture and prolong the shelf life of meat, chicken fillet and fish fillet products (Zhou et al., 2006; Smith and Acton, 2010; Yusop et al., 2011). As soaking with salt solution has no increasing of microbial shelf life, the addition of essential oils is recommended (Van Haute et al., 2017). By adding essential oils, the usage of chemical food additives can be reduced 
(Chouliara et al., 2007).

Therefore, this study aimed to examine the effects of Pangasius fillet soaked in essential oil on the quality and shelf life with simulated storage similar to retail conditions.

\section{Materials and methods}

\subsection{Raw materials}

Fresh Pangasius hypophthalmus fillets were purchased from Pangasius company in An Giang City, Vietnam. Each well-trimmed fillet (skinless, belly off, red meat off and fat off) was about 200-220 g weight. Then, the samples were stored with ice in the polystyrene box and directly transported to the laboratory within 3 hrs. Food grade sodium tripolyphosphate (STPP) (France), sodium chloride $(\mathrm{NaCl})$ (Vietnam), sorbitol (France) were used for the soaking solution. Lemongrass essential oil (LGEO) and mint essential oil (MTEO) were purchased from Vietnam Essential Oil Joint Stock Company, Vietnam.

\subsection{Soaking and storage conditions}

Based on the preliminary study, the optimum condition for Pangasius fillet was soaking for $30 \mathrm{mins}$ with $1.32 \% \mathrm{NaCl}, 1.88 \%$ STPP, and $4.68 \%$ sorbitol. The solutions were combined with lemongrass and mint essential oil (0.1-0.4\%) with ratio $1.5: 1(\mathrm{w} / \mathrm{w})$ and emulsified with $0.01 \%(\mathrm{w} / \mathrm{w})$ Tween 80 (Germany). The fillets were maintained in $4 \pm 1^{\circ} \mathrm{C}$ in a refrigerator (Sanaky, Japan).

The soaking solution should only be used once to avoid contamination. The soaked fillets were then drained for $1 \mathrm{~min}$ and followed by packing in Polystyrene (PS) tray with cellulose moisture absorbent paper (Japan), then wrapped with Polyethylene (PE) film. The packed fillets were stored at refrigerated storage $\left(0-4^{\circ} \mathrm{C}\right)$. The quality changes were tested with an interval period of $0,2,4,6,9$, and 11 days. The experiment was done with two independent replicates.

\subsection{Microbial analysis}

At each interval, a packed fillet from each treatment were aseptically opened and $25 \mathrm{~g}$ of the fish samples were taken using sterile scalpels and tweezers and placed in a sterile stomacher bag (filter $0.5 \mathrm{~mm}$ pore size) (Interscience, France). About $225 \mathrm{~mL}$ of sterile Maximum Recovery Diluent (MRD, Merck, Darmstadt, Germany) was added and the mixture was homogenized for 1 minute. Further decimal dilutions were prepared in MRD. The total viable counts were determined on Plate Count Agar (PCA) (Merck, Darmstadt, Germany) by pour plating. The plates were incubated for 2 days at $37^{\circ}$ $\mathrm{C}$ to determine the total mesophilic counts. Bacterial counts were expressed as $\log _{10}$ colony-forming units (CFU) per $\mathrm{g}$ of sample.

\subsection{Sensorial analysis}

The sensory evaluation of cooked fish was conducted following the method described by Neumann et al. (1983) and using the scoring table by Khalafalla et al. (2015). Cooked fillets were evaluated for the attributes of odour, colour, texture, and taste using a 5point unipolar hedonic scale, with a score range from 1 (very dislike) to 5 (very like). Acceptability and grade of fillets were gained from the total of attributes. The overall score is the total score of all attributes with range 4-20, with 4-7.1 considered as unacceptable and 7.2-20 as acceptable. The fillets were covered in foil and cooked individually in a steamer pot for $6 \mathrm{mins}$ at $100^{\circ} \mathrm{C}$. Then, samples were cut into a size of $3 \times 3 \times 1 \mathrm{~cm}$ before serving to the 20 panelists.

\subsection{Physicochemical analysis}

The peroxide value (PV) was determined according to Rahman et al. (2015). Total Volatile Based-Nitrogen (TVB-N) was based on the steam distillation of an alkalized samples and absorbed by boric acid solution $(1 \%)$ and further titration using the sulfuric acid solution $(0.1 \mathrm{~N})$ according to AOAC (1990). The $\mathrm{pH}$ was determined using a calibrated pH-electrode (Metler Toledo, Schwerzenbach, Switzerland).

\subsection{Statistical analysis}

Data were presented as means \pm standard deviation and a probability value of $0.05(p<0.05)$ were considered significant. One-way analysis of variance (ANOVA) was performed and the mean comparisons were done by Tukey's method. Statistical analysis was performed using Minitab 16 for windows (Minitab, LLC, Pennsylvania, USA)

\section{Results and discussion}

\subsection{Microbial changes}

Total viable counts (TVC) of treated Pangasius fillets during 11 days of refrigerated storage is presented in Figure 1. The initial total viable count of the fillets in this study was 5.5-6.8 log CFU/g. This indicated that the raw material was possibly contaminated during processing (Ahmad et al., 2012; Cai et al., 2015). Fillet without treatment and fillet soaked without essential oil was $7 \log \mathrm{CFU} / \mathrm{g}$ at day 6 of the storage, indicating that limit of acceptability for consumption (Skovgaard, 2003). It is evident that 

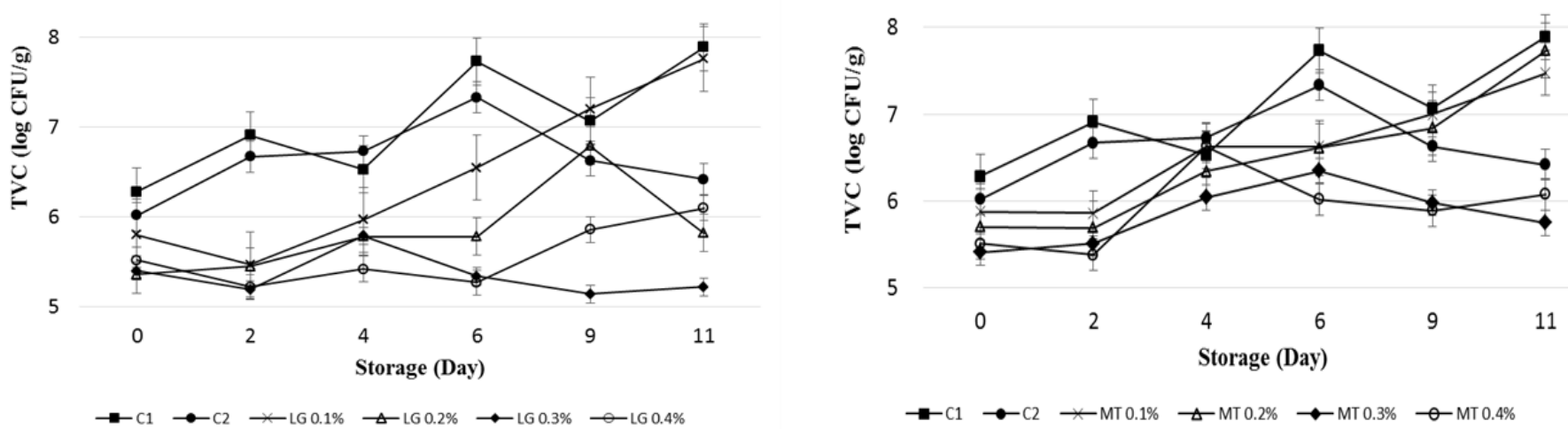

Figure 1. Microbial changes of treated Pangasius fillet during cold storage. C1: Control without soaking; C2: Control soaking without essential oil; MT: Soaking with mint essential oil; and LG: Soaking with lemongrass essential oil.

soaking with STPP, $\mathrm{NaCl}$, and sorbitol without essential oil itself was not enough to extend the shelf life. Lee et al. (1994) reported that gram-positive bacteria are more susceptible to phosphate, meanwhile, Noseda et al. (2012) mentioned that dominant spoilage bacteria in freshwater fish are gram-negative.

Fillets treated with $0.2-0.4 \%$ of lemongrass essential oil (LGEO) showed the extension of shelf life up to 11 days (or 7 days longer) compared to both the controls without soaking $(\mathrm{C} 1)$ and soaked without essential oil (C2). The strong antimicrobial activity of lemongrass attributed to the high citral content. The citral changes the intracellular $\mathrm{pH}$, membrane potential, intracellular ATP concentration, and membrane integrity (Adukwu et al., 2016; De Silva et al., 2017). Mint essential oil (MTEO) showed a positive effect in extending the shelf life of Pangasius fillets). İscan et al. (2002) found that menthol was responsible for the antimicrobial activity of MTEO. At the end of storage, the fillets that soaked with $0.3 \%$ and $0.4 \%$ mint essential oil showed an excellent effect compared to the other samples by remaining below the limit of acceptability for consumption more than 11 days. In conclusion, the $0.3 \%$ concentration of MTEO was effective to apply in soaking solutions to extend the microbial shelf life of Pangasius fillets.

\subsection{Physicochemical properties}

\subsection{1 pH value}

Variations in the value of $\mathrm{pH}$ during the refrigerated storage are presented in Table 1. No significant difference $(p>0.05)$ was observed between the treated fillets and the control samples during each period of storages. However, the $\mathrm{pH}$ of $\mathrm{C} 1$ was consistently low and decrease during storage. The initial $\mathrm{pH}$ was $6.95 \pm 0.15$ then dropped to $6.67 \pm 0.01$ on day 11 . The changes in $\mathrm{pH}$ during storage depend on many factors, such as storage temperature, soaking concentration, species, physiological condition, degradation of protein and enzyme activity (Biscalchin-Grÿschek et al., 2003). The $\mathrm{pH}$ of soaked fillets has a slightly higher $\mathrm{pH}$ than the controls, due to the $\mathrm{pH}$ of soaking solution coming from STPP and essential oils. The microbial loads also affected the $\mathrm{pH}$ of fillets. The accumulation of alkaline compounds (ammonia and TMA, etc.) generated from microbial and enzymatic actions which contribute to an

Table 1. $\mathrm{pH}$ changes of treated Pangasius fillet during cold storage

\begin{tabular}{|c|c|c|c|c|c|c|c|}
\hline \multirow{2}{*}{\multicolumn{2}{|c|}{ Sample }} & \multicolumn{6}{|c|}{ Storage (day) } \\
\hline & & 0 & 2 & 4 & 6 & 9 & 11 \\
\hline \multicolumn{2}{|c|}{$\mathrm{C} 1$} & $6.95 \pm 0.15^{\mathrm{a}}$ & $6.9 \pm 0.02^{\mathrm{a}}$ & $6.65 \pm 0.36^{\mathrm{a}}$ & $6.68 \pm 0.36^{\mathrm{a}}$ & $6.68 \pm 0^{\mathrm{a}}$ & $6.67 \pm 0.01^{\mathrm{a}}$ \\
\hline \multicolumn{2}{|c|}{$\mathrm{C} 2$} & $6.94 \pm 0.25^{\mathrm{a}}$ & $6.79 \pm 0.11^{\mathrm{a}}$ & $6.95 \pm 0.03^{\mathrm{a}}$ & $6.74 \pm 0.21^{\mathrm{a}}$ & $6.99 \pm 0.18^{\mathrm{a}}$ & $6.60 \pm 0.05^{\mathrm{a}}$ \\
\hline \multirow{4}{*}{ LG } & $0.10 \%$ & $6.82 \pm 0.14^{\mathrm{a}}$ & $6.98 \pm 0.2^{\mathrm{a}}$ & $6.84 \pm 0.13^{\mathrm{a}}$ & $6.89 \pm 0.23^{\mathrm{a}}$ & $6.82 \pm 0.10^{\mathrm{a}}$ & $6.7 \pm 0.09^{\mathrm{a}}$ \\
\hline & $0.20 \%$ & $7.12 \pm 0.45^{\mathrm{a}}$ & $6 \pm 0.27^{\mathrm{a}}$ & $7.09 \pm 0.01^{\mathrm{a}}$ & $6.98 \pm 0.27^{\mathrm{a}}$ & $7.04 \pm 0.02^{\mathrm{a}}$ & $6.97 \pm 0.35^{\mathrm{a}}$ \\
\hline & $0.30 \%$ & $7.04 \pm 0.3^{\mathrm{a}}$ & $7.04 \pm 0^{\mathrm{a}}$ & $7.11 \pm 0.18^{\mathrm{a}}$ & $7.11 \pm 0.14^{\mathrm{a}}$ & $6.96 \pm 0.00^{\mathrm{a}}$ & $7.10 \pm 0.52^{\mathrm{a}}$ \\
\hline & $0.40 \%$ & $7.00 \pm 0.35^{\mathrm{a}}$ & $7 \pm 0.03^{\mathrm{a}}$ & $7.04 \pm 0.01^{\mathrm{a}}$ & $6.96 \pm 0.19^{\mathrm{a}}$ & $6.84 \pm 0.05^{\mathrm{a}}$ & $6.80 \pm 0.30^{\mathrm{a}}$ \\
\hline \multirow{4}{*}{ MT } & $0.10 \%$ & $6.91 \pm 0.08^{\mathrm{a}}$ & $6.91 \pm 0.07^{\mathrm{a}}$ & $6.86 \pm 0.15^{\mathrm{a}}$ & $6.87 \pm 0.19^{\mathrm{a}}$ & $6.93 \pm 0.26^{\mathrm{a}}$ & $6.78 \pm 0.09^{\mathrm{a}}$ \\
\hline & $0.20 \%$ & $6.78 \pm 0.23^{\mathrm{a}}$ & $6.78 \pm 0.17^{\mathrm{a}}$ & $6.99 \pm 0.36^{\mathrm{a}}$ & $6.83 \pm 0.24^{\mathrm{a}}$ & $6.82 \pm 0.13^{\mathrm{a}}$ & $6.66 \pm 0.06^{\mathrm{a}}$ \\
\hline & $0.30 \%$ & $6.91 \pm 0.02^{\mathrm{a}}$ & $6.91 \pm 0.13^{\mathrm{a}}$ & $6.77 \pm 0.14^{\mathrm{a}}$ & $6.9 \pm 0.23^{\mathrm{a}}$ & $6.89 \pm 0.32^{\mathrm{a}}$ & $6.65 \pm 0.06^{\mathrm{a}}$ \\
\hline & $0.40 \%$ & $6.96 \pm 0.2^{\mathrm{a}}$ & $6.96 \pm 0.34^{\mathrm{a}}$ & $7.07 \pm 0.03^{\mathrm{a}}$ & $6.98 \pm 0.16^{\mathrm{a}}$ & $7.04 \pm 0.14^{\mathrm{a}}$ & $6.85 \pm 0.18^{\mathrm{a}}$ \\
\hline
\end{tabular}

C1: Control without soaking; C2: Control soaking without essential oil; MT: Soaking with mint essential oil; and LG: Soaking with lemongrass essential oil. Values followed by the same letter within the same row are not significantly different from each other $(p>0.05)$. 
increase of $\mathrm{pH}$ (Ahmad et al., 2012). The compounds of each essential oil also contribute to $\mathrm{pH}$ changes (De Silva et al., 2017).

\subsubsection{Peroxide value $(P V)$}

The peroxide value of treated fillets and the controls was shown in Table 2. There was no significant difference in peroxide value among samples $(p>0.05)$. Peroxide formation is one of the sign oxidative rancidity. During storage, all of the fillets remain below $10 \mathrm{mEq} / \mathrm{kg}$ which means it did not exceed the limit for human consumption. Low peroxide value can be a sign of early oxidation or late stage of severely oxidized fillets where more $\mathrm{H}_{2} \mathrm{O}_{2}$ have been oxidized due to lipid composition of Pangasius itself (Waindu and Jamala, 2013; Rathod et al., 2018). Domiszewski et al. (2011) mentioned, despite a substantial influence of heat treatment on the amount of both primary and secondary oxidation products, the lipids maintained good quality with peroxide value of sample was below $3 \mathrm{mEq} / \mathrm{kg}$. Variation of PV also depends on the composition of feed, particularly its lipid profile which determines the amount and composition of fish lipid fatty acids. Orban et al. (2008), reported lipid content of Pangasius fillets were dominantly saturated fatty acids (41.1-47.8\%) and weakly unsaturated fatty acids (12.5-18.85\%) from total $1.1-3 \%$ of lipid content.

\subsubsection{Total Volatile Based-Nitrogen (TVB-N) content}

TVB-N content serves as an indicator for the assessment of the freshness of fish. Enzymes from spoilage microorganism, particularly proteolytic enzyme can metabolize the amino acids of the fish muscle producing a wide variety of volatile compounds resulting in off-flavours and odours. TVB-N in freshwater fish and their product commonly comes from ammonia (Tokur et al., 2006).
TVB-N content of treated Pangasius fillets during refrigerated storage for 11 days shown in Table 3. The significant difference $(p<0.05)$ shows that $\mathrm{C} 1$ had the highest TVB-N content and show a rapid increase from 7.4 to $14.7 \mathrm{mgN} / 100 \mathrm{~g}$ on day 0 to day 11 . Abbas et al. (2009) explained that the higher $\mathrm{a}_{\mathrm{w}}$ tend to support more microorganisms. It can be seen that the $\mathrm{C} 1$ had the highest amount of TVC which resulted in the highest TVB-N compared to others (Table 3).

During storage, the TVB-N content of all samples was below the limit of acceptability for fish; $35 \mathrm{mg}$ $\mathrm{N} / 100 \mathrm{~g}$ muscle (Commission of the European Communities, 1995). TVB-N content values for Pangasius fillets remained consistently low during storage indicating that Pangasius fish may not produce nitrogenous compounds to the same during storage (Tobin and Gormley, 2016).

The addition of MTEO and LGEO to the soaking solution did not give a significant effect on reducing TVB-N content. Ahmad et al. (2012) reported that sea bass slices wrapped with gelatine film incorporated $25 \%$ lemongrass essential oil during the 12 days of storage at $4^{\circ} \mathrm{C}$ have a significant effect in lowering TVB-N. Meanwhile, in this study, the concentration of essential oil was much lower to give effect in TVB-N. The intrinsic properties of the food such as fat, protein, $\mathrm{pH}$, as well as the environment (storage temperature, packaging, etc.), may influence the function of essential oils (Burt and Reinders, 2003). Factors such as low pH, temperature, $\mathrm{O}_{2}$ concentrations; and high salt content enhance the antimicrobial effect of the essential oils. Meanwhile, low water activity and high content of protein and fat were one of the barriers for bacteria from essential oils (Gómez-Estaca et al., 2010).

Table 2. Peroxide value of treated Pangasius fillet during cold storage

\begin{tabular}{|c|c|c|c|c|c|c|c|}
\hline \multirow{2}{*}{\multicolumn{2}{|c|}{ Sample }} & \multicolumn{6}{|c|}{ Storage (day) } \\
\hline & & 0 & 2 & 4 & 6 & 9 & 11 \\
\hline \multicolumn{2}{|r|}{$\mathrm{C} 1$} & $0.33 \pm 0.04^{\mathrm{a}}$ & $0.55 \pm 0.21^{\mathrm{a}}$ & $0.50 \pm 0.20^{\mathrm{a}}$ & $0.77 \pm 0.29^{\mathrm{a}}$ & $0.85 \pm 0^{\mathrm{a}}$ & $0.63 \pm 0.00^{\mathrm{a}}$ \\
\hline \multicolumn{2}{|r|}{$\mathrm{C} 2$} & $0.36 \pm 0.04^{\mathrm{a}}$ & $0.68 \pm 0.49^{\mathrm{a}}$ & $0.46 \pm 0.18^{\mathrm{a}}$ & $0.61 \pm 0.40^{\mathrm{a}}$ & $0.68 \pm 0.40^{\mathrm{a}}$ & $0.35 \pm 0.16^{\mathrm{a}}$ \\
\hline \multirow{4}{*}{ LG } & $0.10 \%$ & $0.3 \pm 0.04^{\mathrm{a}}$ & $0.45 \pm 0.25^{\mathrm{a}}$ & $0.48 \pm 0.02^{\mathrm{a}}$ & $0.69 \pm 0.08^{\mathrm{a}}$ & $0.81 \pm 0.58^{\mathrm{a}}$ & $0.61 \pm 0.30^{\mathrm{a}}$ \\
\hline & $0.20 \%$ & $0.33 \pm 0.14^{\mathrm{a}}$ & $0.65 \pm 0.16^{\mathrm{a}}$ & $0.51 \pm 0.02^{\mathrm{a}}$ & $0.73 \pm 0.37^{\mathrm{a}}$ & $0.53 \pm 0.33^{\mathrm{a}}$ & $0.48 \pm 0.25^{\mathrm{a}}$ \\
\hline & $0.30 \%$ & $0.25 \pm 0.07^{\mathrm{a}}$ & $0.55 \pm 0.21^{\mathrm{a}}$ & $0.65 \pm 0.44^{\mathrm{a}}$ & $0.58 \pm 0.35^{\mathrm{a}}$ & $0.5 \pm 0.33^{\mathrm{a}}$ & $0.56 \pm 0.47^{\mathrm{a}}$ \\
\hline & $0.40 \%$ & $0.26 \pm 0^{\mathrm{a}}$ & $0.6 \pm 0.37^{\mathrm{a}}$ & $0.56 \pm 0.18^{a}$ & $0.4 \pm 0.23^{\mathrm{a}}$ & $0.45 \pm 0.16^{\mathrm{a}}$ & $0.7 \pm 0.42^{\mathrm{a}}$ \\
\hline \multirow{4}{*}{ MT } & $0.10 \%$ & $0.25 \pm 0.02^{\mathrm{a}}$ & $0.65 \pm 0.35^{\mathrm{a}}$ & $0.7 \pm 0.28^{\mathrm{a}}$ & $0.71 \pm 0.40^{\mathrm{a}}$ & $0.78 \pm 0.40^{\mathrm{a}}$ & $0.53 \pm 0.28^{\mathrm{a}}$ \\
\hline & $0.20 \%$ & $0.18 \pm 0.11^{\mathrm{a}}$ & $0.75 \pm 0.44^{\mathrm{a}}$ & $0.86 \pm 0.51^{\mathrm{a}}$ & $0.61 \pm 0.35^{\mathrm{a}}$ & $0.81 \pm 0.44^{\mathrm{a}}$ & $0.46 \pm 0.04^{\mathrm{a}}$ \\
\hline & $0.30 \%$ & $0.33 \pm 0.04^{\mathrm{a}}$ & $0.3 \pm 0.09^{\mathrm{a}}$ & $0.51 \pm 0.21^{\mathrm{a}}$ & $0.48 \pm 0.11^{\mathrm{a}}$ & $0.9 \pm 0.23^{\mathrm{a}}$ & $0.43 \pm 0.09^{\mathrm{a}}$ \\
\hline & $0.40 \%$ & $0.31 \pm 0.21^{\mathrm{a}}$ & $0.5 \pm 0^{\mathrm{a}}$ & $0.61 \pm 0.11^{\mathrm{a}}$ & $0.53 \pm 0.23^{\mathrm{a}}$ & $0.65 \pm 0.11^{\mathrm{a}}$ & $0.48 \pm 0.07^{\mathrm{a}}$ \\
\hline
\end{tabular}

C1: Control without soaking; C2: Control soaking without essential oil; MT: Soaking with mint essential oil; and LG: Soaking with lemongrass essential oil. Values followed by the same letter within the same row are not significantly different from each other $(p>0.05)$. 
Table 3. TVB-N of treated Pangasius fillet during cold storage

\begin{tabular}{|c|c|c|c|c|c|c|c|}
\hline \multirow{2}{*}{\multicolumn{2}{|c|}{ Sample }} & \multicolumn{6}{|c|}{ Storage (day) } \\
\hline & & 0 & 2 & 4 & 6 & 9 & 11 \\
\hline \multicolumn{2}{|c|}{$\mathrm{C} 1$} & $7.36 \pm 2.67^{\mathrm{a}}$ & $10.6 \pm 1.03^{\mathrm{a}}$ & $10.9 \pm 1.19^{\mathrm{a}}$ & $12.3 \pm 0.74^{\mathrm{a}}$ & $11.8 \pm 0^{\mathrm{a}}$ & $14.7 \pm 0^{\mathrm{a}}$ \\
\hline \multicolumn{2}{|c|}{$\mathrm{C} 2$} & $6.72 \pm 0.59^{\mathrm{a}}$ & $7.98 \pm 2.37^{\mathrm{a}}$ & $9.87 \pm 2.67^{\mathrm{a}}$ & $9.67 \pm 1.78^{\mathrm{ab}}$ & $9.14 \pm 0.44^{\mathrm{a}}$ & $9.03 \pm 0.89^{b}$ \\
\hline \multirow{4}{*}{ LG } & $0.10 \%$ & $5.46 \pm 1.18^{\mathrm{a}}$ & $6.51 \pm 1.48^{\mathrm{a}}$ & $9.03 \pm 0.23^{\mathrm{a}}$ & $9.67 \pm 1.19^{\mathrm{ab}}$ & $10.9 \pm 0^{\mathrm{a}}$ & $10.7 \pm 0.89^{\mathrm{ab}}$ \\
\hline & $0.20 \%$ & $6.72 \pm 2.37^{\mathrm{a}}$ & $6.93 \pm 0.29^{\mathrm{a}}$ & $8.40 \pm 0^{\mathrm{a}}$ & $8.83 \pm 1.19^{\mathrm{ab}}$ & $7.98 \pm 0.59^{\mathrm{a}}$ & $8.30 \pm 1.93^{\mathrm{b}}$ \\
\hline & $0.30 \%$ & $5.88 \pm 1.19^{\mathrm{a}}$ & $7.35 \pm 3.26^{\mathrm{a}}$ & $8.93 \pm 0.45^{\mathrm{a}}$ & $7.78 \pm 1.49^{\mathrm{b}}$ & $9.24 \pm 2.37^{\mathrm{a}}$ & $8.19 \pm 0.89^{b}$ \\
\hline & $0.40 \%$ & $6.51 \pm 2.08^{\mathrm{a}}$ & $7.98 \pm 1.18^{\mathrm{a}}$ & $8.40 \pm 0.6^{\mathrm{a}}$ & $9.46 \pm 0.89^{\mathrm{ab}}$ & $10.9 \pm 0.59^{\mathrm{a}}$ & $9.24 \pm 1.18^{\mathrm{b}}$ \\
\hline \multirow{4}{*}{ MT } & $0.10 \%$ & $5.67 \pm 3.27^{\mathrm{a}}$ & $8.19 \pm 0.89^{\mathrm{a}}$ & $8.41 \pm 1.78^{\mathrm{a}}$ & $9.04 \pm 0.89^{\mathrm{ab}}$ & $9.77 \pm 2.52^{\mathrm{a}}$ & $8.82 \pm 1.18^{b}$ \\
\hline & $0.20 \%$ & $5.25 \pm 2.09^{\mathrm{a}}$ & $7.35 \pm 0.29^{\mathrm{a}}$ & $8.2 \pm 0.29^{\mathrm{a}}$ & $9.46 \pm 0.89^{\mathrm{ab}}$ & $9.25 \pm 1.18^{\mathrm{a}}$ & $11.9 \pm 1.48^{\mathrm{ab}}$ \\
\hline & $0.30 \%$ & $5.67 \pm 0.89^{\mathrm{a}}$ & $8.40 \pm 2.37^{\mathrm{a}}$ & $8.62 \pm 1.48^{\mathrm{a}}$ & $8.41 \pm 0^{\mathrm{ab}}$ & $10.5 \pm 0^{\mathrm{a}}$ & $9.14 \pm 1.33^{\mathrm{b}}$ \\
\hline & $0.40 \%$ & $6.93 \pm 3.86^{\mathrm{a}}$ & $7.98 \pm 0.59^{\mathrm{a}}$ & $8.30 \pm 0.45^{\mathrm{a}}$ & $11.0 \pm 1.04^{\mathrm{ab}}$ & $9.9 \pm 0.29^{\mathrm{a}}$ & $9.66 \pm 0.59^{b}$ \\
\hline
\end{tabular}

C1: Control without soaking; C2: Control soaking without essential oil; MT: Soaking with mint essential oil; and LG: Soaking with lemongrass essential oil. Values followed by the same letter within the same row are not significantly different from each other $(p>0.05)$.

\subsection{Sensory evaluation}

The overall score of cooked treated Pangasius fillets is shown in Table 4. There is no significant difference $(p>0.05)$ between each sample during storage. However, $\mathrm{C} 1$ showed significant overall sensory degradation during storage compared to the others. $\mathrm{C} 1$ was categorized as unacceptable on day 9 . Although $\mathrm{C} 2$ was still within the acceptable limit on day 9, sensory evaluation ended on that day since it has reached the limit of acceptability in terms of microbial load. The soaking solution with or without EO contributes to a higher preference of panellists, as a result of STPP which increased the water retention in the fillets to make the fillets juicier and a better appearance (Gonçalves et al., 2018). Therefore, to keep overall sensory of fillets within an acceptable score until 11 days, the addition of LGEO from $0.2 \%-0.4 \%$ and MTEO into the soaking solution is favourable. The microorganisms as the spoilage bacteria of fillets contribute to the degradation of odour,

appearance, texture, and taste (Jouki et al., 2014). The natural compounds of each EO reduce the action of endogenous enzymes and microbial activity, which also inhibit microbial-induced softening in the fillets (Cai et al., 2015). The strong volatile compounds such as menthol and citral in both MTEO and LGEO capable to disguise the fishy odour of fillets. Another advantage of soaking is the $\mathrm{NaCl}$, sorbitol, STPP, and EO contribute to the flavour which enriched the taste of treated fillets compared to C1 (Abbas et al., 2009; Yusop et al., 2011).

In this study, it is evident that it takes a longer period of storage for the panellist to figure out the spoilage in the fillets. Therefore, Mai and Huynh (2017) suggested that the shelf life of Pangasius fillets stored at low temperatures should be based on an acceptable level of TVC instead of sensory evaluation, especially sensory quality index.

\section{Conclusion}

Table 4. Overall sensory changes of cooked Pangasius fillet during cold storage

\begin{tabular}{|c|c|c|c|c|c|c|c|}
\hline \multirow{2}{*}{\multicolumn{2}{|c|}{ Sample }} & \multicolumn{6}{|c|}{ Storage (day) } \\
\hline & & 0 & 2 & 4 & 6 & 9 & 11 \\
\hline \multicolumn{2}{|c|}{$\mathrm{C} 1$} & $14.3 \pm 1.29^{\mathrm{a}}$ & $13.9 \pm 2.47^{\mathrm{a}}$ & $12.5 \pm 0.99^{\mathrm{a}}$ & $12.0 \pm 0.47^{\mathrm{a}}$ & $6.08 \pm 0^{\mathrm{a}}$ & \\
\hline \multicolumn{2}{|c|}{$\mathrm{C} 2$} & $15.9 \pm 0.11^{\mathrm{a}}$ & $15.0 \pm 2.15^{\mathrm{a}}$ & $14.6 \pm 1.7^{\mathrm{a}}$ & $13.9 \pm 0.11^{\mathrm{a}}$ & $14.5 \pm 0^{\mathrm{a}}$ & \\
\hline \multirow{4}{*}{ LG } & $0.10 \%$ & $14.7 \pm 2.23^{\mathrm{a}}$ & $15.0 \pm 2.38^{\mathrm{a}}$ & $15.5 \pm 0.99^{\mathrm{a}}$ & $14.4 \pm 0.58^{\mathrm{a}}$ & $11 \pm 0^{\mathrm{a}}$ & $10 \pm 0^{\mathrm{a}}$ \\
\hline & $0.20 \%$ & $16.1 \pm 0.46^{\mathrm{a}}$ & $14.5 \pm 3.09^{\mathrm{a}}$ & $15.7 \pm 0.42^{\mathrm{a}}$ & $15.1 \pm 1.41^{\mathrm{a}}$ & $14.1 \pm 2.12^{\mathrm{a}}$ & $13.7 \pm 0.29^{\mathrm{a}}$ \\
\hline & $0.30 \%$ & $15.0 \pm 0.34^{\mathrm{a}}$ & $13.7 \pm 0.90^{\mathrm{a}}$ & $14.8 \pm 1.41^{\mathrm{a}}$ & $15.0 \pm 0.35^{\mathrm{a}}$ & $15.1 \pm 1.27^{\mathrm{a}}$ & $13.1 \pm 1.92^{\mathrm{a}}$ \\
\hline & $0.40 \%$ & $14.9 \pm 0.43^{\mathrm{a}}$ & $14.9 \pm 1.12^{\mathrm{a}}$ & $15.7 \pm 0.42^{\mathrm{a}}$ & $13.7 \pm 1.39^{\mathrm{a}}$ & $15.1 \pm 1.65^{\mathrm{a}}$ & $13.7 \pm 0^{\mathrm{a}}$ \\
\hline \multirow{4}{*}{ MT } & $0.10 \%$ & $17.2 \pm 1.03^{\mathrm{a}}$ & $15.8 \pm 2.22^{\mathrm{a}}$ & $14.1 \pm 0.99^{\mathrm{a}}$ & $14.5 \pm 0.23^{\mathrm{a}}$ & $15.4 \pm 0^{\mathrm{a}}$ & $14.4 \pm 0^{\mathrm{a}}$ \\
\hline & $0.20 \%$ & $16.6 \pm 0.94^{\mathrm{a}}$ & $15.9 \pm 1.14^{\mathrm{a}}$ & $16.2 \pm 1.7^{\mathrm{a}}$ & $14.9 \pm 1.76^{\mathrm{a}}$ & $15.4 \pm 1.29^{\mathrm{a}}$ & $14.4 \pm 0^{\mathrm{a}}$ \\
\hline & $0.30 \%$ & $18 \pm 0.94^{\mathrm{a}}$ & $15.2 \pm 0.35^{\mathrm{a}}$ & $15.2 \pm 1.41^{\mathrm{a}}$ & $15 \pm 2.59^{\mathrm{a}}$ & $14.8 \pm 0^{\mathrm{a}}$ & $15.0 \pm 0^{\mathrm{a}}$ \\
\hline & $0.40 \%$ & $16.1 \pm 0.24^{\mathrm{a}}$ & $16.7 \pm 0.64^{\mathrm{a}}$ & $13.4 \pm 1.02^{\mathrm{a}}$ & $15.6 \pm 0.47^{\mathrm{a}}$ & $17 \pm 0^{\mathrm{a}}$ & $14.0 \pm 0.04^{\mathrm{a}}$ \\
\hline
\end{tabular}

C1: Control without soaking; C2: Control soaking without essential oil; MT: Soaking with mint essential oil; and LG: Soaking with lemongrass essential oil. Values followed by the same letter within the same row are not significantly different from each other $(p>0.05)$. 
The incorporation of essential oil to the soaking solution indicated that lemongrass and mint essential oil improves the quality of Pangasius fillet. However, the lemongrass essential oil has a better performance in inhibiting microbial activity and also inhibiting TVB-N formation compared to the mint essential oil. Therefore, it is recommended to incorporate $0.2 \%$ lemongrass essential oil for the Pangasius fillets to extend the shelf life during cold storage.

\section{Acknowledgement}

The authors would like to gratefully acknowledge the VLIR-OUS and Can Tho University Improvement Project, VN14-P6 supported by Japanese ODA loan for the administrative and financial support.

\section{References}

Abbas, K., Saleh, A., Mohamed, A. and Lasekan, O. (2009). The relationship between water activity and fish spoilage during cold storage: A review. Journal of Food, Agriculture and Environment, 7(3/4), 8690. https://doi.org/10.1016/j.fm.2006.12.005

Adukwu, E.C., Bowles, M., Edwards-Jones, V. and Bone, H. (2016). Antimicrobial activity, cytotoxicity and chemical analysis of lemongrass essential oil (Cymbopogon flexuosus) and pure citral. Applied Microbiology and Biotechnology, 100(22), 96199627. https://doi.org/10.1007/s00253-016-7807-y

Ahmad, M., Benjakul, S., Sumpavapol, P. and Nirmal, N.P. (2012). Quality changes of sea bass slices wrapped with gelatin film incorporated with lemongrass essential oil. International Journal of Food Microbiology, 155(3), 171-178. https:// doi.org/10.1016/j.ijfoodmicro.2012.01.027

AOAC. (1990). Association of Official Analytical Chemists, Official Methods of Analysis: Changes in Official Methods of Analysis Made at the Annual Meeting. Supplement. Washington, D.C., USA: Association of Official Analytical Chemists.

Biscalchin-Grÿschek, S., Oetterer, M. and Gallo, C.R. (2003). Characterization and frozen storage stability of minced Nile tilapia (Oreochromis niloticus) and red tilapia (Oreochromis spp.). Journal of Aquatic Food Product Technology, 12(3), 57-69. https:// doi.org/10.1300/J030v12n03_06

Burt, S. (2004). Essential oils: their antibacterial properties and potential applications in foods-a review. International Journal of Food Microbiology, 94(3), 223-253. https://doi.org/10.1016/ j.ijfoodmicro.2004.03.022

Burt, S.A. and Reinders, R.D. (2003). Antibacterial activity of selected plant essential oils against
Escherichia coli O157: H7. Letters in Applied Microbiology, 36(3), 162-167. https:// doi.org/10.1046/j.1472-765X.2003.01285.x

Cai, L., Cao, A., Li, Y., Song, Z., Leng, L. and Li, J. (2015). The effects of essential oil treatment on the biogenic amines inhibition and quality preservation of red drum (Sciaenops ocellatus) fillets. Food Control, 56, 1-8. https://doi.org/10.1016/ j.foodcont.2015.03.009

Cassens, R.G. (1997). Composition and safety of cured meats in the USA. Food Chemistry, 59(4), 561-566. https://doi.org/10.1016/S0308-8146(97)00007-1

Chouliara, E., Karatapanis, A., Savvaidis, I. and Kontominas, M. (2007). Combined effect of oregano essential oil and modified atmosphere packaging on shelf-life extension of fresh chicken breast meat, stored at $4^{\circ}$ C. Food Microbiology, 24(6), 607-617. https://doi.org/10.1016/j.fm.2006.12.005

Commission of the European Communities. (1995). 95/149/EC: Commission Decision of 8 March 1995 fixing the total volatile basic nitrogen (TVB-N) limit values for certain categories of fishery products and specifying the analysis methods to be used. Official Journal of the European Communities, 268, 84-87.

De Silva, B., Jung, W.-G., Hossain, S., Wimalasena, S., Pathirana, H. and Heo, G.-J. (2017). Antimicrobial property of lemongrass (Cymbopogon citratus) oil against pathogenic bacteria isolated from pet turtles. Laboratory Animal Research, 33(2), 84-91. https:// doi.org/10.5625/lar.2017.33.2.84

Domiszewski, Z., Bienkiewicz, G. and Plust, D. (2011). Effects of different heat treatments on lipid quality of striped catfish (Pangasius hypophthalmus). Acta Scientiarum Polonorum Technologia Alimentaria, 10 (3), 359-373.

Gómez-Estaca, J., De Lacey, A.L., López-Caballero, M., Gómez-Guillén, M. and Montero, P. (2010). Biodegradable gelatin-chitosan films incorporated with essential oils as antimicrobial agents for fish preservation. Food Microbiology, 27(7), 889-896. https://doi.org/10.1016/j.fm.2010.05.012

Gonçalves, A., Souza, M. and Regis, R. (2018). Effects of different levels of food additives on weight gain, cook-related yield loss, physicochemical and sensorial quality of Nile tilapia fillets (Oreochromis niloticus). International Food Research Journal, 25 (5), 2068-2080.

İşcan, G., Kirimer, N., Kürkcüoğlu, M.N., Başer, H.C. and Demirci, F. (2002). Antimicrobial screening of Mentha piperita essential oils. Journal of Agricultural and Food Chemistry, 50(14), 39433946. https://doi.org/10.1021/jf011476k 
Jouki, M., Yazdi, F.T., Mortazavi, S.A., Koocheki, A. and Khazaei, N. (2014). Effect of quince seed mucilage edible films incorporated with oregano or thyme essential oil on shelf life extension of refrigerated rainbow trout fillets. International Journal of Food Microbiology, 174, 88-97. https:// doi.org/10.1016/j.ijfoodmicro.2014.01.001

Karl, H., Lehmann, I., Rehbein, H. and Schubring, R. (2010). Composition and quality attributes of conventionally and organically farmed Pangasius fillets (Pangasius hypophthalmus) on the German market. International Journal of Food Science and Technology, 45(1), 56-66. https://doi.org/10.1111/ j.1365-2621.2009.02103.x

Khalafalla, F.A., Ali, F.H. and Hassan, A.-R.H. (2015). Quality improvement and shelf-life extension of refrigerated Nile tilapia (Oreochromis niloticus) fillets using natural herbs. Beni-Suef University Journal of Basic and Applied Sciences, 4(1), 33-40. https://doi.org/10.1016/j.bjbas.2015.02.005

Lee, R.M., Hartman, P.A., Olson, D.G. and Williams, F.D. (1994). Bactericidal and bacteriolytic effects of selected food-grade phosphates, using Staphylococcus aureus as a model system. Journal of Food Protection, 57(4), 276-283. https:// doi.org/10.4315/0362-028X-57.4.276

Mai, N. and Huynh, V. (2017). Kinetics of quality changes of Pangasius fillets at stable and dynamic temperatures, simulating downstream cold chain conditions. Journal of Food Quality, 2017, 2865185. https://doi.org/10.1155/2017/2865185

Neumann, R., Molnár, P. and Arnold, S. (1983). Sensorische Lebensmitteluntersuchung. Germany: Fachbuchverlag, Leipzig

Noseda, B., Islam, M.T., Eriksson, M., Heyndrickx, M., De Reu, K., Van Langenhove, H. and Devlieghere, F. (2012). Microbiological spoilage of vacuum and modified atmosphere packaged Vietnamese Pangasius hypophthalmus fillets. Food Microbiology, 30(2), 408-419. https:// doi.org/10.1016/j.fm.2011.12.025

Orban, E., Nevigato, T., Lena, G.D., Masci, M., Casini, I., Gambelli, L. and Caproni, R. (2008). New trends in the seafood market. Sutchi catfish (Pangasius hypophthalmus) fillets from Vietnam: Nutritional quality and safety aspects. Food Chemistry, 110(2), 383-389.

j.foodchem.2008.02.014

Phan, L.T., Bui, T.M., Nguyen, T.T., Gooley, G.J., Ingram, B.A., Nguyen, H.V., Nguyen, P.T. and De Silva, S.S. (2009). Current status of farming practices of striped catfish, Pangasianodon hypophthalmus in the Mekong Delta, Vietnam.
Aquaculture, 296(3), 227-236. https:// doi.org/10.1016/j.aquaculture.2009.08.017

Rahman, M., Hossain, M., Rahman, S., Amin, M. and Oh, D.-H. (2015). Evaluation of physicochemical deterioration and lipid oxidation of beef muscle affected by freeze-thaw cycles. Korean Journal For Food Science of Animal Resources, 35(6), 772. https://doi.org/10.5851/kosfa.2015.35.6.772

Rathod, N., Pagarkar, A., Pujari, K., Shingare, P., Satam, S., Phadke, G. and Gaikwad, B. (2018). Status of valuable components from Pangasius: A Review. International Journal of Current Microbiology and Applied Sciences, 7(4), 2106-2120. https:// doi.org/10.20546/ijcmas.2018.704.241

Skovgaard, N. (2003). Microorganisms in Foods 7: Microbiological Testing in Food Safety Management -By International Commission for the Microbiological Specifications of Foods (ICMSF). Kluwer Academic/Plenum Publishers, New York. International Journal of Food Microbiology, 2(89), 291-292. https://doi.org/10.1016/S0168-1605(03) 00163-6

Smith, D.P. and Acton, J.C. (2010). Marination, cooking and curing of poultry products. In Casey, C.M., Alvarado, C.Z. and Sams, A.R. (Eds.) Poultry Meat Processing, $2^{\text {nd }}$ ed., p. 257-280. Boca Raton: CRC Press. https://doi.org/10.1201/b15805

Tobin, L. and Gormley, R. (2016). Fish Freshness at retail level. Retrieved on August 20, 2019 from UCD Website: https://www.ucd.ie/foodandhealth/t4media/ Supplement $\% 2021$ A\%20Fish\%20freshness.pdf.

Tokur, B., Ozkütük, S., Atici, E., Ozyurt, G. and Ozyurt, C.E. (2006). Chemical and sensory quality changes of fish fingers, made from mirror carp (Cyprinus carpio L., 1758), during frozen storage $\left(-18^{\circ} \mathrm{C}\right)$. Food Chemistry, 99(2), 335-341. https:// doi.org/10.1016/j.foodchem.2005.07.044

Van Haute, S., Raes, K., Devlieghere, F. and Sampers, I. (2017). Combined use of cinnamon essential oil and $\mathrm{MAP} /$ vacuum packaging to increase the microbial and sensorial shelf life of lean pork and salmon. Food Packaging and Shelf Life, 12, 51-58. https:// doi.org/10.1016/j.fpsl.2017.02.004

Waindu, C. and Jamala, G. (2013). A Study of Rancidity of Fish Sold In Mubi Markets, Adamawa State, Nigeria. IOSR Journal of Agriculture and Veterinary Science, 6(2), 47-50.

Yusop, S.M., O'Sullivan, M. and Kerry, J. (2011). Marinating and enhancement of the nutritional content of processed meat products. In Kerry, J.P. and Kerry, J.F. (Eds.), Processed Meats, p. 421-449. 
USA: Woodhead Publishing Limited. https:// doi.org/10.1533/9780857092946.3.421

Zhou, A., Benjakul, S., Pan, K., Gong, J. and Liu, X. (2006). Cryoprotective effects of trehalose and sodium lactate on tilapia (Sarotherodon nilotica) surimi during frozen storage. Food Chemistry, 96(1), 96-103.

https://doi.org/10.1016/ j.foodchem.2005.02.013 